\title{
Studies on Control of Purple Nutsedge, Cyperus rotundus L., a Perennial Weed in Upland Fields
}

\author{
-Growth and Change of Carbohydrate Content in Nutsedge- \\ Toshiki Yasuda, Yuji Yamasue and Kunikazu Ueki \\ Faculty of Agriculture, Kyoto University, Kyoto
}

\begin{abstract}
Summary
1. Growth and reproduction of purple nutsedge (Cyperus rotundus L.) were studied for proper timings in the mechanical and chemical control measures. Changes of carohydrate contents both in the aerial and underground parts were also determined throughout the growing season to find the extent of sugar transport for the vegetative reproduction below the ground.

2. When parent tuber segment each having a bud were planted in Wagner pots, the weed grew vigorously and started new tuber formation two weeks after planting. In the fourth week the number of leaves reached maximal 19 and there was a drastic reduction in the $\mathrm{T} / \mathrm{R}$ ratio. Floral formation was initiated 5 weeks after planting.

3. Among the carbohydrates determined fructose content was little changed both in aerial and underground parts throughout the growing season. However, a remarkable increase in sucrose and glucose contents was shown in the underground part from fourth through fifth week when active sugar transport must have been required for the formation and maturation of tuber.

4. From results of the experiment repeated mowing or tillage every two weeks after its emergence is suggested for control of this perennial weed. Chemical treatment between full leaf development is also applicable with those herbicides which have mobility to the underground part along with sugar transport.
\end{abstract}

\section{カラスビシャクの球茎などの生育に及ぼす 2,3 の環境条件について $(2)$}

\author{
武田薬品工業 $\mathrm{KK}$ 中央研究所生薬研究所 長 尾 弓 郎
}

\begin{abstract}
前報3) に引き続きカラスビシャクの球茎, 木子, 珠芽 の生育に及ぼす環境条件について検討した。カラスビシ ヤクの発生する環境条件は他の雑草より比較的限られて いる。たとえば，カラスビシャクは熟畑の指標植物の一 つになりらる5) といわれるように, 畑地や樹園地または その周辺などに見いだせても，道端や河原，その他多く の雑草が定着できそうな空地などにはほとんど発生しな い。また非散布型1) の植物で, 人為的に移動させない限 り, 珠芽, 種子は親球芽の周囲に落下し, その狭い範囲 で生存を続け，次第に個体密度を高くしていくょうであ る。そこで, これらの諸条件を考慮して, 肥料の三要素 や植付け密度に対寸る球茎などの生育を検討した。さら
\end{abstract}

に植付け深度と生育の関係についても実験を重ね, 若干 の知見を得たので，その概要を報告する。

本研究の実施にあたり終始摡篤な御指導と御校閲を賜 った京都大学教授植木邦和博士に深甚なる感謝の意を表 する。また絶えず御教示と御激励をいただいた武田薬品 工業株式会社生薬研究所所長後藤 實博士, 同副所長松 岡敏郎博士，並びに種々有益な御助言をいただいた農薬 研究所主任研究員萩本 宏博士に深謝する。

\section{1. 供試材料および方法}

本実験では，前報3)で述べた京都市左京区修学院地区 で採取したカラスビシャクを用いた。また用土は前報と 
同じものである。

\section{実験 1. 肥料と生育の関係}

球茎，木子，球芽の生育に及ぼす肥料の影響を検討す るため, 1976 年に窒素 $(\mathrm{N})$, 燐酸 $(\mathrm{P})$, カリ $(\mathrm{K})$ に対 する耐肥試験を実施した。試験区としては，10 a 当た り, 成分量で 40,70 および $100 \mathrm{~kg}$ の 3 区と対照の無肥 料区を設け， N， P，K K はそれぞれ硫安, 熔燐, 塩化力 リを用いた。肥料は，各区とも 5 月 6 日から 30 日ごと に 4 回分施とした。また, 1977 年には三要素試験を行っ たが, 各要素を $10 \mathrm{a}$ 当たり成分量 $70 \mathrm{~kg}$ で組み合わせ, $\mathrm{N} \cdot \mathrm{P} \cdot \mathrm{K}, \mathrm{N} \cdot \mathrm{P}, \mathrm{N} \cdot \mathrm{K}, \mathrm{P} \cdot \mathrm{K}, \mathrm{N}, \mathrm{P}, \mathrm{K}$ の 7 肥料 区と対照の無肥料区を設けた。この場合も 5 月 15 日か ら 30 日ごとに 4 回分施とした。実験はすべて $1 / 2,000 \mathrm{a}$ ポットを用い，耐肥試験は 1 ポット当たり 6 個の球茎 を, 5 反覆で 1976 年 4 月 15 日に, また三要素試験は 1 ポット当たり 10 個の球茎を, 4 反覆で 1977 年 4 月 25 日 に植え付けた。な押, 前者の球茥生重は平均 $1.07 \mathrm{~g}$, 後 者は平均 $0.54 \mathrm{~g}$ であった。

\section{実験 2. 植付け密度と生育の関係}

植付け密度は $1 / 2,000 \mathrm{a}$ ポットに $5,10,20$ および 30 個の 4 段階とした。各区には平均 $0.46 \mathrm{~g}$ の球茎を，5反 覆で 1977 年 4 月 16 日に植え付け, 同年 10 月 20 日に掘 り上げ，球重，木子，珠芽について調查した。

\section{実験 3. 植付け深度と生育の関係}

1976 年には $1 / 2,000 \mathrm{a}$ ポット， 1977 年には直径 30 $\mathrm{cm}$ ，長さ $100 \mathrm{~cm}$ の土管を用い，深さも $5 ， 10 ， 15$ およ び $20 \mathrm{~cm}$ として検討した。各区とも大球茎, 生重平均 $1.10 \mathrm{~g}$ と小球茎, 生重平均 $0.32 \mathrm{~g}$ を 20 球ずつ同年 5 月 11 日および 6 月 28 日の 2 回に植え付け, 同年 11 月 26 日に掘り上げて調查した。

\section{2. 実 験 結 果}

\section{実験 1. 肥料と生育の関係}

\section{1) 耐 肥 性}

三要素 $\mathrm{N}, \mathrm{P}, \mathrm{K}$ の球茎，木子，珠芽の生育に及ぼす 影響を検討したところ，第 1 図に示す結果を得た。 $\mathrm{N}$ 肥 料の影響は, $10 \mathrm{a}$ 当たり $70 \mathrm{~kg}$ で球茎の肥大率が最も高 く，対照区の 100 に対して 183 の值を示した。しかし $100 \mathrm{~kg}$ 施用区では 163 となり，70 kg 区より低かった。 また木子数も， $\mathrm{N}$ 肥料 $10 \mathrm{a}$ 当たり $70 \mathrm{~kg}$ 区で最も多く, その比率は 164 であった。さらに珠芽数についてみる と， $\mathrm{N}$ 肥料区の 70 抢よび $100 \mathrm{~kg}$ の両区でそれぞれ 193 および 153 であった。一方，K 打よび $\mathrm{P}$ 肥料の影響は $\mathrm{N}$ 肥料のように明確でなかった。すなわち， $\mathrm{P}$ 肥料 70 , $100 \mathrm{~kg}$ で球茎重が減少，40,70 kg で珠芽数が増える傾
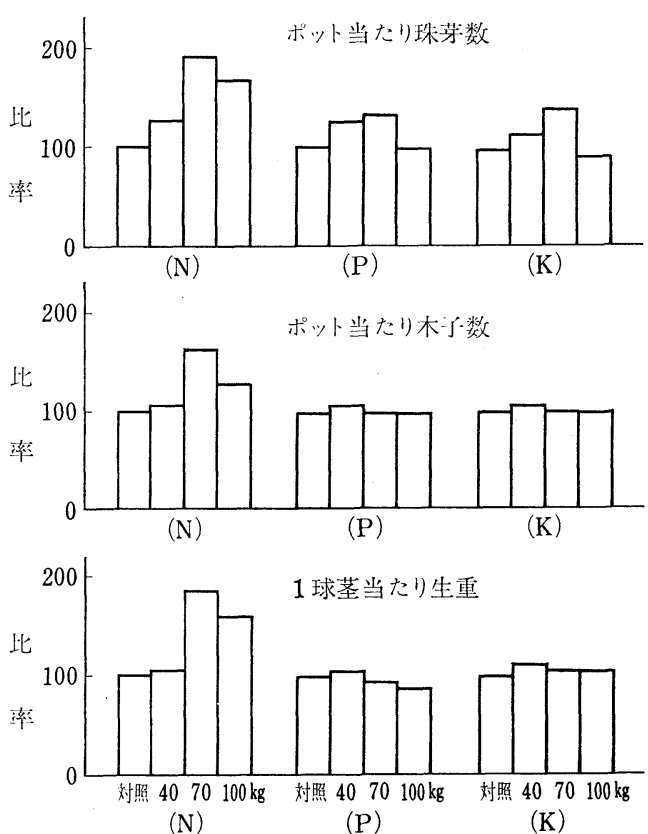

第 1 図 カラスビシャクの球茎などの耐肥性

注）対照 (無肥料)を100 とした場合の值

向をそれぞれ示したが，有意差は認められなかった。ま た, $\mathrm{K}$ 肥料では $40,70 \mathrm{~kg}$ で珠芽数がやや増えたが，そ の他の形質では，施用量の差異による違いはみられなか った。

\section{2) 三要素試験}

三要素の球茎などに及ぼす影響は第 2 図に示すとおり である。まず球茎重についてみると，N・P・K区が最も 重く, 対照無肥料区の 100 亿対し 270 の高い值を示し た。次いで $\mathrm{N} \cdot \mathrm{P}$ 区で，そのほか $\mathrm{N}, \mathrm{N} \cdot \mathrm{K}$ 区が高く， $\mathrm{N}$ を含まない $\mathrm{P} ・ \mathrm{~K} ， \mathrm{P} ， \mathrm{~K}$ 区は対照区とほとんぞ差は なかった。

木子数では $\mathrm{N} \cdot \mathrm{P} \cdot \mathrm{K}$ 区が最も多く, 次いで $\mathrm{N} \cdot \mathrm{K}>\mathrm{N}$ $>\mathrm{N} \cdot \mathrm{P}$ で， $\mathrm{P} \cdot \mathrm{K}, \mathrm{P}, \mathrm{K}$ 区は対照区と変らなかった。 珠芽数，珠芽重も同じ傾向で，球茎重，木子数に対する 場合々同様 $\mathrm{N} \cdot \mathrm{P} \cdot \mathrm{K}$ 三要素区が最も大きかった。次い で $\mathrm{N} \cdot \mathrm{K}>\mathrm{N} \cdot \mathrm{P}$ であった。 $\mathrm{P} \cdot \mathrm{K} ， \mathrm{~N} ， \mathrm{~K}$ は対照区と同 程度で，P 区は最低であった。

\section{実験 2. 植付け密度と生育の関係}

植付け密度として $1 / 2,000 \mathrm{a}$ ポットに $5,10,20$ およ び 30 個の球茎を植え付け，その生育状況を検討したと ころ，第 1 表に示寸結果を得た。すなわち，1 個当たり の球茎重は 5 個区が最も高く, その生重の平均值は 1.81 $\mathrm{g}$ を示し, $30 \mathrm{~cm}$ 区の約 1.7 倍であった。この植付け数 と球茎重との間には $r=-0.95$ の相関が認められた。 

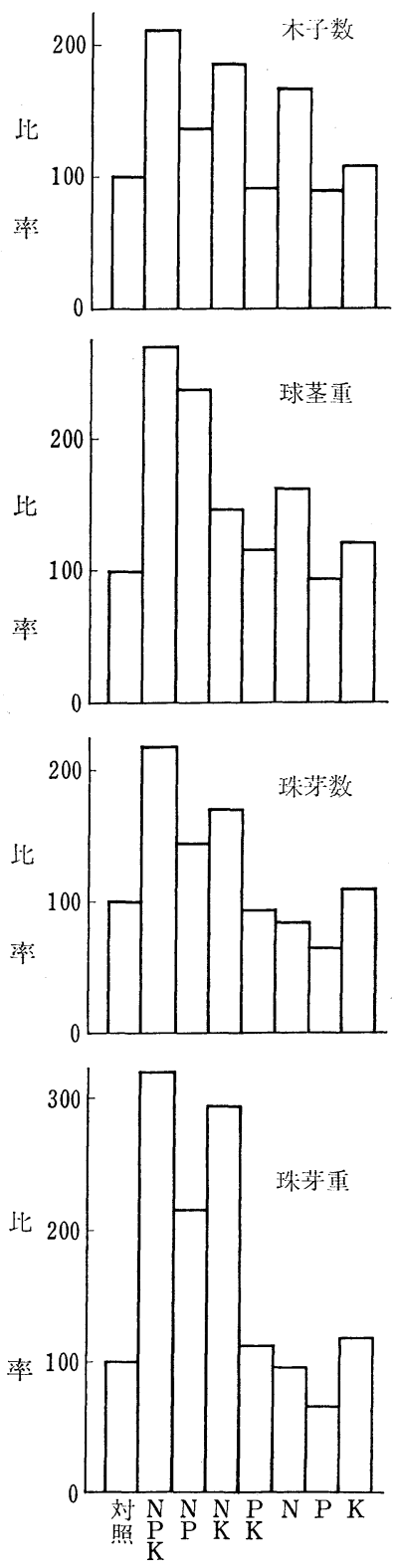

第 2 図 三要素肥料試験

注）対照(無肥料)を100とした場合の值
つぎに，1 球茎に着 く木子数は各区間に 有意差はなく, 平均 $1.2 \sim 1.5$ 個が形成 されたが, 植付け密 度の小さいほど多い 傾向を示した。一 方, 珠芽数の方は 5 個区で 1 球茎当たり 平均 5.6 個であるの に対し，30 個区では 平均 2.9 個で, 5 個 区の約 $52 \%$ にすぎ なかった。珠芽重は 各区間に全く差異が なく, $0.16 \sim 0.18 \mathrm{~g}$ であった。

実験 3. 植付け深 度と生育の関係

深度に関する実験 は，植付け時期によ る差異を考慮し， 1977 年 5 月 11 日と 6 月 28 日の 2 回に 分けて $5,10,15$ および $20 \mathrm{~cm}$ の深度 に植え付けた。第 2 表のように, 深度が 深いほど萌芽は遅れ たが，最終的には 15 $\mathrm{cm}$ 区までは $100 \%$ に近い萌芽率を示 し, $20 \mathrm{~cm}$ 区でやや 低下した。また球茎 の生重, 肥大率など は第 3 表に示した が, $5 \mathrm{~cm}$ 区の肥大率 を 100 とすれば，深度 $20 \mathrm{~cm}$ 区では大球茎で 46 , 小球茎 区で 63 となり, 深いほど球菱の生育は抑えられた。こ の傾向は 6 月 28 日植えの場合もほぼ同様であった。球 茎に着く木子数は，大球茎を用いた 5 月 11 日植えの場 合では，深度 $5 \mathrm{~cm}$ 区で平均 1.9 個を示し， $20 \mathrm{~cm}$ 区の 1.1 個より多かったが， 6 月 28 日植えではこのような差 異は認められなかった。また小球茎を用いた区では，両 植付け期とも平均 1.0 個で, 深度による差異はなかっ
第 1 表 植付け密度と生育状況

\begin{tabular}{c|c|c|c|c}
\hline \hline 密 度 & $\begin{array}{c}\text { 球茥生重 } \\
(\mathrm{g})\end{array}$ & $\begin{array}{c}\text { 木 } \\
\text { (個) }\end{array}$ & $\begin{array}{c}\text { 数 } \\
\text { (個) }\end{array}$ & $\begin{array}{c}\text { 芽数 } \\
(\mathrm{g})\end{array}$ \\
\hline 5 & $1.81 \pm 0.24$ & $1.48 \pm 0.28$ & $5.56 \pm 1.68$ & $0.18 \pm 0.04$ \\
10 & $1.45 \pm 0.22$ & $1.36 \pm 0.23$ & $4.00 \pm 2.16$ & $0.18 \pm 0.04$ \\
20 & $1.17 \pm 0.35$ & $1.32 \pm 0.23$ & $2.98 \pm 1.04$ & $0.17 \pm 0.02$ \\
30 & $1.05 \pm 0.20$ & $1.18 \pm 0.11$ & $2.90 \pm 0.48$ & $0.16 \pm 0.02$ \\
\hline
\end{tabular}

注 1) 密度：1ポット当たりの植付け個数

2）数值：1珠茎当たり平均值 \pm S. D.

第 2 表 植付深度と萌芽状況

\begin{tabular}{|c|c|c|c|c|}
\hline 植付㐨月日 & \multicolumn{2}{|c|}{5 月 11 日 } & \multicolumn{2}{|c|}{6 月 28 日 } \\
\hline 植付江深度 & $\begin{array}{c}\text { 植付け後15日 } \\
\text { 目の萌芽率 }\end{array}$ & 最終萌芽率 & $\begin{array}{c}\text { 植付け後 } 15 \text { 日 } \\
\text { 目の萌芽率 }\end{array}$ & 最終萌芽率 \\
\hline $5 \mathrm{~cm}$ & $100 \%$ & $100 \%$ & $50 \%$ & $100 \%$ \\
\hline 10 & 90 & 100 & 35 & 100 \\
\hline 15 & 15 & 100 & 10 & 85 \\
\hline 20 & 0 & 65 & 3 & 60 \\
\hline
\end{tabular}

注） 萌芽率は大球茎区と小球茎区の萌芽率の平均值

第 3 表 植付け澡度と生育状況

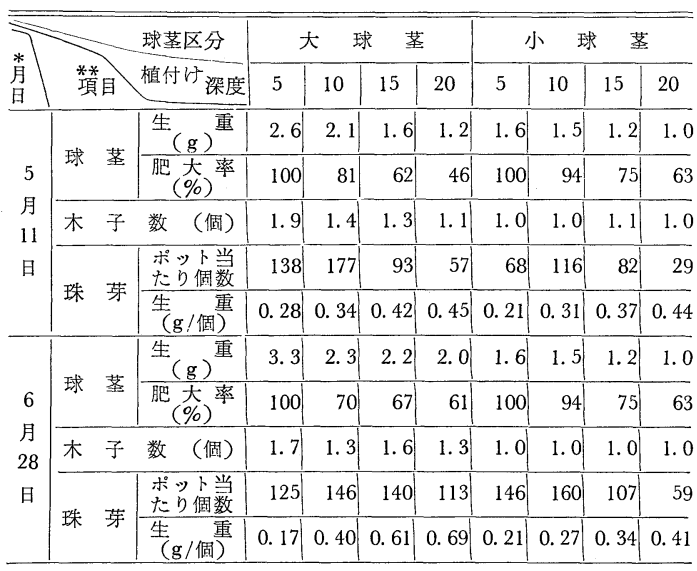

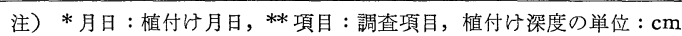
た。

球芽数は $10 \mathrm{~cm}$ 区で最も多く，それより浅いほど，ま た深くなるにしたがい減少し， $20 \mathrm{~cm}$ 区で最も少なかっ た。たとえば， 5 月 11 日植えの深度 $10 \mathrm{~cm}$ の大球茎区 では，ポット当たり平均 177 個で, $20 \mathrm{~cm}$ 区の平均 57 個 に対し 311 の比率を示した。しかし1珠芽重は深いほど 大きく, 深度 $5 \mathrm{~cm}$ の大球茎区が $0.17 \sim 0.28 \mathrm{~g}$ を示した のに対し， $20 \mathrm{~cm}$ 区では $0.45 \sim 0.69 \mathrm{~g}$ であった。

\section{3. 考察}

カラスビシャクは熟畑の指標植物になりうるという報 告があるよらに, 肥料成分が多いと考えられる畑地, 樹 園地の内外で発生することから，肥料に対する生育状況 を検討した。施用量は，ポット試験であるため，灌水に よる肥料の流亡などを考慮して一般農作物に比較すると 
多すぎると考えられる量としたが, 球茎の生重は $10 \mathrm{a}$ 当 たり $70 \mathrm{~kg}$ が最も優れ, 次いで $100 \mathrm{~kg}$ であった。また 燐酸, カリ肥料区では燐酸の $70,100 \mathrm{~kg}$ 区で対照区よ

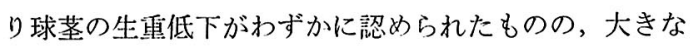
生育障㫪はみられなかった。一方, 三要素試験では, 三 要素の揃った $\mathrm{N} \cdot \mathrm{P} \cdot \mathrm{K}$ 区での球茎，木子，珠芽の数， 重量ともすべて他区にまさっていた。その外 $N \cdot P, N$ ・ $\mathrm{K}$ および $\mathrm{N}$ など, $\mathrm{N}$ を含む区は球茎重, 木子数の増大 に, また $\mathrm{N} \cdot \mathrm{P}, \mathrm{N} \cdot \mathrm{K}$ は珠芽数, 珠芽重の增大にそれ ぞれ寄与した。舜酸の生育に及ぼす影響は不明な点が多 かったが, 多量の燐酸は生育の阻害を生じることが推察 された。肥料試験は土壤条件によって影響される面が大 きいから，本実験で直ちに耐肥性の高い植物であるとは 言えないにしても, 以上の結果から, カラスビシャクの 生育, 增殖に対しては $\mathrm{N}$ 成分の影響が大きく, いわゆ る好窒素雑草 ${ }^{2}$ のように考えられる。

次に植付け密度であるが, カラスビシャクは親株の周 囲にかなりの密度で生育していることから, 株の密度と 球茎の生育および珠芽の形成状況を検討することにし た。すなわち $1 / 2,000 \mathrm{a}$ ポットに 5 個ずつ植え付けた区 の球茎は，10，20 および 30 個を植え付けた区の球茎生 重より大きかった。この傾向は珠芽数にも認められ，5 個区の 1 球茎当たり珠芽数は 5.6 個で最も多かった。一 方, 20 および 30 個区はそれぞれ平均 3.0 および 2.9 個 で両区間の珠芽数に差異のないことから，1/2,000 a の 面積に 20 個以上の極端な植付方をしない限り, 1 球茎 当たりの珠芽形成数はほとんど変らないようである。な お，本実験に用いた球茎は $0.46 \mathrm{~g}$ 程度のものであった が，前報引で述べたように，供試球茎の大きさによって 肥大率に差異があるから, 本実験の結果とやや異なった 傾向が得られるように考えられるので, 更に詳細な実験 を行う予定である。

最後に, 植付け深度と球茎の生育との関係であるが, 前報3では佐々木ら までとしたが，予備実験から，球茎は $10 \mathrm{~cm}$ 以上の梁い 所からでも萌芽することが分ったので，本実験では 20 $\mathrm{cm}$ までの区を設けて実験したところ, 第 3 図のように 葉柄が伸長して萌芽した。その萌芽率は $5 \sim 15 \mathrm{~cm}$ 区に 比較すると $20 \mathrm{~cm}$ 区は $60 \sim 65 \%$ でやや低かったが, 畑 の土袞中にかなり梁く寸き込まれても萌身し, 生育を続 けるように推察された。また植付け時期を 5 月 11 日お よび 6 月 28 日の 2 回としたが，この両者間に生育の差 異はほとんど認められなかった。一方, 深度が深くなる につれて萠芽数が減少するためか, 珠芽数は少なくな る。しかし，樑い区では珠芽が地中に形成されるので,

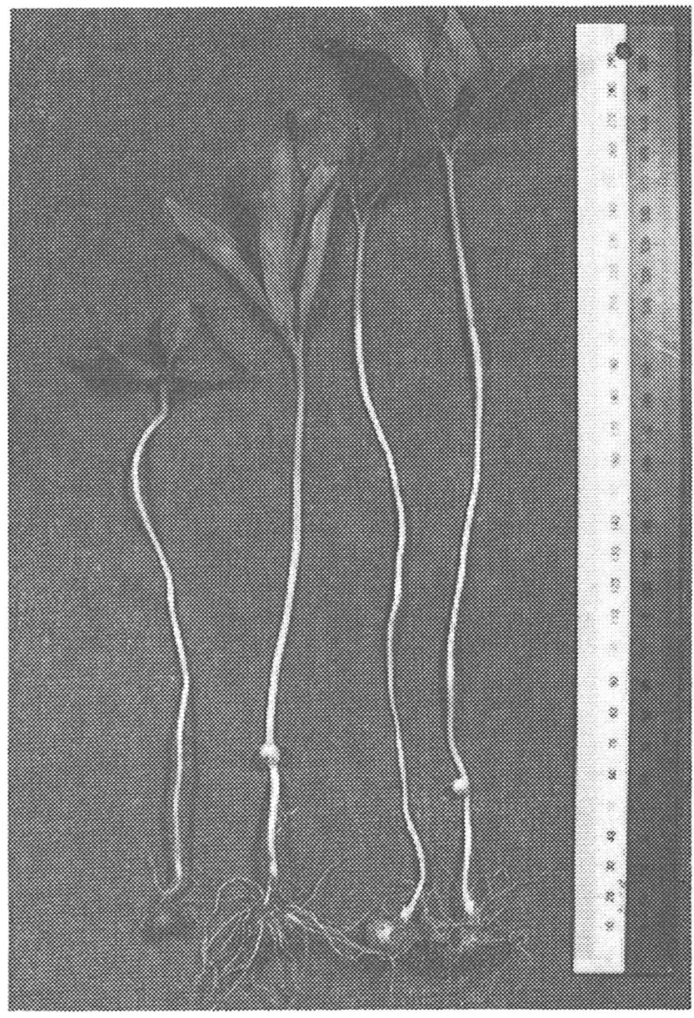

第 3 図 カラスビシャクの葉柄の伸長状況

注）左から，球茎植付计深度 $5,10,15,20 \mathrm{~cm}$ の場命

発根, 萠芽する珠芽むあり, 1 珠芽当たりの生重は重く なる結果を得たが，これは前報”致する。

以上, カラスビシャクの球茎の肥大は個体密度によっ て影響を受けること，またカラスビシャクは，耕うんな どにより深く寸き込まれても萌芽生育のできる雑草のよ らに思秃る。

\section{4. 摘}

要

（1）カラスビシャクの球茎，木子および珠芽に及ほ す三要素 $\mathrm{N}, \mathrm{P}, \mathrm{K}$ 肥料について検討し, カラスビシ ヤクは好窒素性の植物であることが分った。

（2）植付け密度と球茎などの生育の関係を $1 / 2,000$ a ポットで検討した結果， 5 個植え区は，20および 30 個植え区に対し, 球茎の肥大, 木子数, 珠芽数などでま さっていた。

（3）植付け深度を $5,10,15$ および $20 \mathrm{~cm}$ として, 球茎や珠芽数などの生育状況を検討したところ, $20 \mathrm{~cm}$ 程度の樑い所からでも萌匆すること，しかし球茎の肥 大, 木子数は浅い方がよいことなどを明らかにした。 


\section{引用 文 献}

1) 堀田 满：植物の分布と分化. 三省堂, 東京, (1974).

2) 河野昭一：種と進化. 三省堂, 東京, (1969).

3）長尾郎：カラスビシャクの球茎などの生育に及注す2,3の環㑽 条件について (1). 雑草研究 22 (4), 189 193 (1977).
4) 佐々木 享・山崎慎一：カラスビシャクの発生と繁殖の様相. 雑草 研究 7, 34 37 (1968).

5) 清水正元：太刀洗に於ける雑草の群落, 生態学的研究. 生態学研究 12, 148 151 (1949).

(1978 年 3 月 27 日受理)

\title{
The Effect of the Environmental Conditions on the Growth of Pinellia ternata Breit. (2)
}

\author{
Yumiro NagaO \\ Pharmacognostic Research Laboratories, Takeda Chemical Industries Ltd., Kyoto
}

\section{Summary}

The experiments were performed to clarify the effect of fertilization level, planting rate and planting depth on the growth of Pinellia ternata. The results obtained were as follows:

1. P. ternata has rather the adaptability for heavy manuring; $7 \mathrm{~kg} \mathrm{~N}, \mathrm{P}$ and $\mathrm{K} /$ are increased significantly the weight of corms, the number of bulblets and aerial tubers. And it was recognized to be a nitrogen-favored plant from the fertilizer reqirement experiments.

2. The weight of corms and the number of aerial tubers were progressively greater in the plot of 5 corms per pot $(1 / 2,000$ are $)$ than 20 or 30 corms.

3. The corms sprouted $60 \sim 50 \%$ even in the $20 \mathrm{~cm}$ depth and positive and significant relations between the growth of corms and planting depth were obtained. The shallow planting, less than $5 \mathrm{~cm}$ depth, increases the weight of corms and the number of aerial tubers.

\section{熟畑化過程における雑草植生の変遷に関する研究 \\ 第 6 報 原野から熟畑に至る過程における雑草植生の変化*}

\author{
新潟大学農学部附属農場 菅 原 清 康
}

\section{緒言}

従来, 雑草植生の変遷については ELLENBERG ${ }^{1)}$, 北 海道農試 ${ }^{2)}$, 飯泉 ${ }^{3)}$, 川廷 ${ }^{4)}$, 草下・緑川 ${ }^{5,6)}$, 児玉・桜 井 $^{7)}$, 中沢 ${ }^{8)}$, 沼田 ${ }^{9)}$, 大迫 ${ }^{10)}$, 清水 ${ }^{11)}$ な゙多数の報告が あるが，これらの大部分は, 雑草植生の変遷を, 主とし て群落の形成, 生活型, 土㙥の肥沃度, 耐性範囲あるい は耕種操作による発生草種や草重などから究明しょうと したもので, 純粋に土壤の理化学的性質の変化から追求 を行ったものではないようにみられる。そこで著者は， 開墾された原野が耕うんや土壌改良資材の投入によって
熟畑化する過程で生起する土壤の化学的性質の変化，お よびこれに伴ら雑草植生の対応を観察し, この両者の関 係から植生変遷の機構を探索しょうとした。

\section{実験材料ならびに実験方法}

1957 年 12 月新潟県中蒲原郡村松町字石曽根地区の暗 褐灰黄色細埴土の比較的古い火山灰黒ボク土壤からなる 平坦な原野 $76.3 \mathrm{a}(106 \mathrm{~m} \times 72 \mathrm{~m})$ を選定し, 地上部の雑 草を除去した後, 大型機で耕深 $28 \mathrm{~cm}$ に反転耕起し, 縦 横各 5 回の砕土均平を行い開墾した。試験区の構成は第 1 表に示寸通りで, 1958 年から '72 年まで毎年処理を行

* 大要は, 日本雑草学会第 17 回講演会（1978 年 4 月）に拈いて発表。 